\title{
Removal of Bunches or Spikelets Is Not Effective for the Control of Aceria guerreronis
}

\author{
José Wagner S. Melo ${ }^{1}$ and Cleiton A. Domingos \\ Depto. Agronomia, Universidade Federal Rural de Pernambuco, Recife, PE, \\ 52171-900, Brazil
}

\section{Angelo Pallini \\ Depto. Entomologia, Universidade Federal de Viçosa, Viçosa, MG, 36570-000, Brazil}

\author{
José Eudes M. Oliveira \\ Entomologia, Embrapa Semiárido, Petrolina, PE, 56302-970, Brazil
}

Manoel G.C. Gondim, Jr.

Depto. Agronomia, Universidade Federal Rural de Pernambuco, Recife, PE, 52171-900, Brazil

Additional index words. Cocos nucifera, coconut mite, mite, ecology, bunch management

\begin{abstract}
Worldwide, there remains a reliance on repeated chemical applications as a control strategy for the coconut mite, but these are impractical, not economical, and environmentally hazardous. In this study, the damage severity of Aceria guerreronis on coconut fruits was studied under different conditions to investigate the effects of bunch management on the amount of damage to newly produced bunches. The damage was evaluated using a diagrammatic scale under four different conditions: 1) plants with bunches removed; 2 ) bunches with the distal portion of the spikelet removed; 3 ) bunches sprayed monthly with abamectin ( $9 \mathrm{~g}$ a.i./ha); and 4$)$ control plants. For each treatment, two fruits from bunches 1 to 6 (counted from the last open inflorescence) from 10 plants were randomly collected every month for $\mathbf{4}$ months. The removal of the distal portion of the spikelets had no effect on the damage level of new bunches but delayed the damage severity by $\approx 1$ month. After the removal of all of the bunches, the damage severity was restored within 2 months to the newly produced bunches, whereas the chemical control with abamectin kept the $A$. guerreronis damage intensity at a low level. Thus, the removal of bunches or the distal portion of spikelets is not an effective practice for the control of A. guerreronis in areas with high levels of infestation.
\end{abstract}

The coconut mite [Aceria guerreronis Keifer (Acari: Eriophyidae)] is a serious pest of coconuts in the Americas and Africa, and it has rapidly become established in some major coconut-producing countries in Asia (LawsonBalagbo et al., 2008; Moore and Howard, 1996; Ramaraju et al., 2002). The mite damages the fruit during the early developmental stages, causing surface scars and premature fruit fall (Moore and Howard, 1996). When not aborted, the fruits injured by A. guerreronis show a reduced weight, size, and volume of coconut water and albumen (Negloh et al., 2011); the losses may reach up to $60 \%$ (Moore, 2000). Aceria guerreronis may be present on fruits of

Received for publication 27 Jan. 2012. Accepted for publication 26 Mar. 2012.

This research was funded by the National Council of Scientific and Technological Development (CNPq), by the Pernambuco State Foundation for Research Aid (FACEPE) and by the Coordination for the Improvement of Higher Education- Personnel (CAPES).

${ }^{1}$ To whom reprint requests should be addressed; e-mailwagnermelo@hotmail.com. different ages (Fernando et al., 2003; Galvão et al., 2011; Lawson-Balagbo et al., 2008; Moore and Alexander, 1987), and the injuries caused by this mite become more evident with the age of the bunch (Fernando et al., 2003; Moore and Alexander, 1987). The highest population densities occur in the fourth bunch ( $\approx 4$ months old) (Fernando et al., 2003; Galvão et al., 2011) with $\approx 16 \%$ of the fruit surface damaged and $\approx 3000$ mites per fruit (Galvão et al., 2008). The fruits of different ages exhibit different severities of damage and, consequently, different densities of mites. The densities of mites or the damage to different fruits can be quantified through the use of the diagrammatic scales of damage developed by Galvão et al. (2008), and the level of damage can be used as a parameter for evaluating the effectiveness of different control practices.

Several control methods have been evaluated and used or have potential against the mite, including chemical control (Moore et al., 1989), resistant cultivars (Mariau, 1986; Moore and Alexander, 1990), and biological control (Domingos et al., 2010; Lawson-Balagbo et al., 2008; Melo et al., 2011). Currently, the only way to control this pest is through chemical control (Julia and Mariau, 1979; Moore et al., 1989). However, as a result of the height of the plant and the fact that the pest is hidden under the perianth, which is not reachable by many acaricides, chemical control seems impracticable for small-scale farmers, who lack the appropriate equipment and supplies (Moore and Howard, 1996; Ramaraju et al., 2002). In addition, frequent use of such a practice could raise the cost of production excessively and eventually cause problems as a result of residue on the coconut products (Moore and Howard, 1996).

Simple practices such as the removal of infested bunches and cleaning the tops of the plants, although little investigated, have been recommended for small-scale production for which the use of acaricides becomes prohibitive (Alencar et al., 2001; Ferreira, 2009). According to Howard (2008), the actual practices include the removal of all of the bunches, thus eliminating the pests in these fields for a certain period of time. However, these practices present conflicting results and can lead to a disruption of the economic benefit.

Because the coconut mite exhibits limited space occupancy under the perianth, dispersal within fruit structures is a core step for population dynamics (Lima et al., 2012). Therefore, this study aimed at answering the following questions: 1) How long is the tree free of damage after removal of bunches? 2) Can the removal of the distal portion of the spikelet delay the peak of damage? 3) Can different forms of management of the bunches change the distribution pattern of damage? To answer these questions, the damage levels by A. guerreronis on coconut fruits was studied under different bunch management conditions using the diagrammatic scale developed by Galvão et al. (2008).

\section{Materials and Methods}

The research was conducted at a commercial plantation of Green Dwarf coconut plants, $\approx 5 \mathrm{~m}$ in height, in Petrolina, State of Pernambuco, Brazil (long. $08^{\circ} 58^{\prime} \mathrm{S}$, lat. $35^{\circ} 11^{\prime} \mathrm{W}$ ) from Nov. 2008 to Mar. 2009. According to the classification of Koeppen, the local climate belongs to the BSwh, a climatically arid region (Kottek et al., 2006), with the rainy season concentrated between January and April. The environment data (temperature, rainfall, and wind speed) were registered at a weather station located $4 \mathrm{~km}$ from the experimental area. The average temperature recorded ranged from 24 to $29^{\circ} \mathrm{C}$, the average rainfall ranged from 0 to $5 \mathrm{~mm}$ per day, and average wind speed ranged from 0.5 to $9.0 \mathrm{~m} \cdot \mathrm{s}^{-1}$. During the experiment, all of the plants received the same volume of water $\left(300 \mathrm{~L} \cdot \mathrm{d}^{-1}\right.$ for each plant by the drip method) and were fertilized using the fertigation [ $810 \mathrm{~g}$ per plant per year of each nutrient: nitrogen (urea) and potassium (potassium chloride)]. Green Dwarf palms after initiation of the reproductive stage under suboptimal conditions of cultivation (conditions of most cultivation in the world) produce an inflorescence every $30 \mathrm{~d}$. After fertilization of the female flowers, the inflorescences 


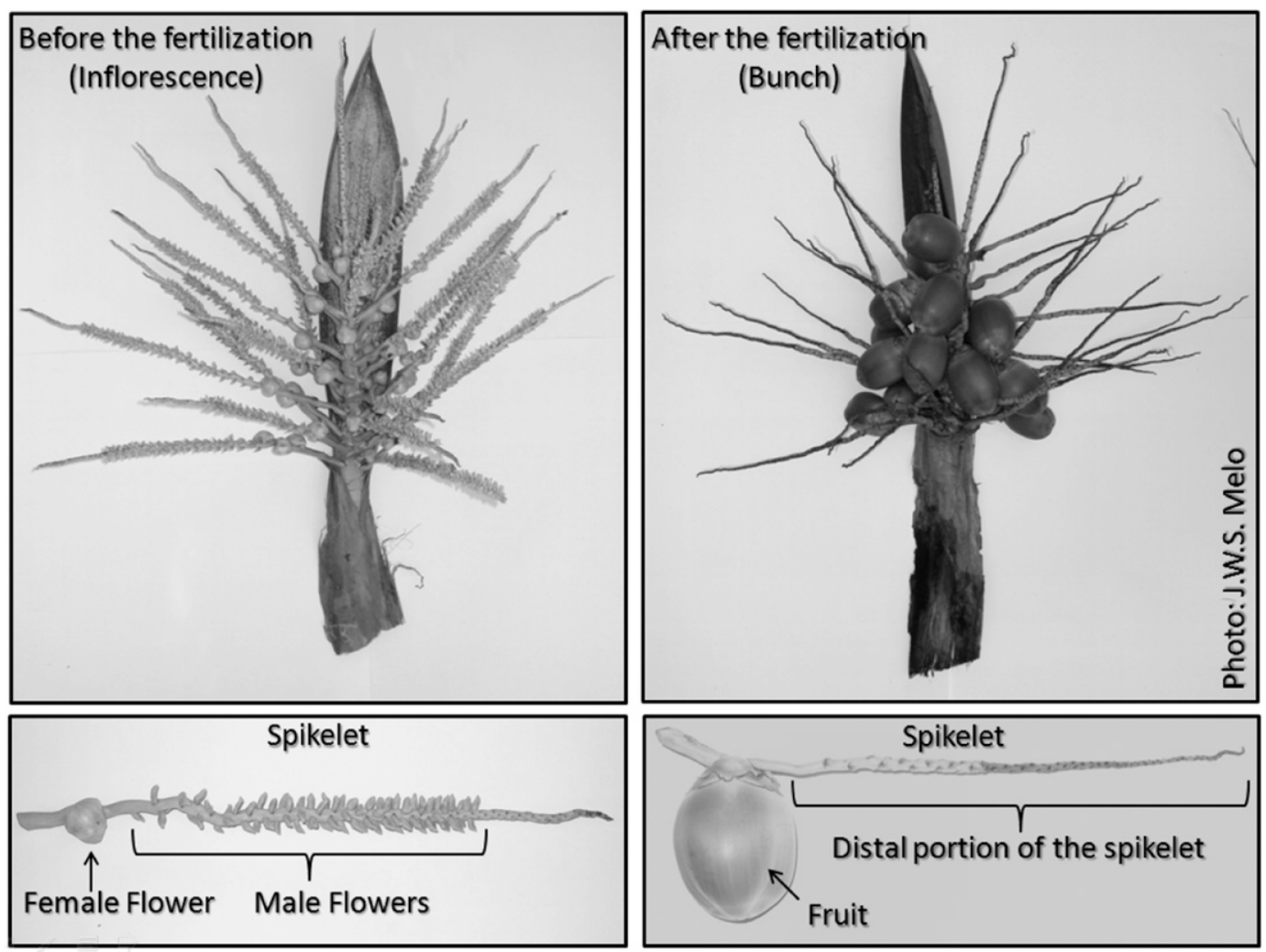

Fig. 1. Reproductive structures of coconut palm (C. nucifera): spikelets from inflorescence with female and male flowers (left), and spikelets from bunch with fruits (right).

are called bunches (Fig. 1). Seven months after anthesis, the bunches reach the harvest point. In the conditions of cultivation of the present study, the harvest point is reduced from 7 to 4 months, and each new inflorescence is emitted in $\approx 17 \mathrm{~d}$.

Detection of damage levels before initiating treatments. To determine the initial levels of damage, four groups of 10 plants were randomly chosen and marked. Each group was separated by two rows of plants, and each of the 40 plants was sampled (replications). For each sampling, two fruits from six bunches of different ages were randomly collected. The six young bunches were samples (assigning 0 for the inflorescence and counting the bunches downward, bunch numbers correspond to approximate bunch age in months after pollination). In the remainder of this article, these bunches are referred to as bunches 1, 2, 3, 4, 5, and 6 , respectively. The damage caused by A. guerreronis to the fruits from all four of the groups was estimated by the scale described by Galvão et al. (2008). In the scale proposed by Galvão et al. (2008), the extent of the necrotic area caused by $A$. guerreronis is determinate in relation to the proportion of the total nut surface for nuts of the Green Dwarf variety of a specific age (bunches 1 to 6). These authors elaborated a diagrammatic scale with damage levels of $1 \%$, $2 \%, 4 \%, 8 \%, 16 \%, 32 \%, 48 \%$, and $70 \%$.

The damage level to each plant from each group was obtained from the average scores of the fruits from bunches 2 to 6 . All fruits from bunch 1 were disregarded because no damage was observed. The average damage level per plant was tested for normality (Kolmogorov: normal test) and homogeneity of variance (Bartlett's test) and, subsequently, submitted to analysis of variance (ANOVA); comparisons were performed by Tukey's test ( $\alpha=$ 0.05 ) using the SAS statistical software (SAS Institute, 2002).

Effect of bunch management on fruit damage levels. In each group of previously selected plants, a different bunch management (treatment) was conducted. In Treatment 1 (bunches removed), all of the bunches were removed, leaving only the remaining parts of the inflorescence. In Treatment 2 (spikelets removed), the distal portion of all spikelets from bunches 1 to 6 was removed $1 \mathrm{~cm}$ distal to the last fruit to avoid the walking of $A$. guerreronis between fruits over spikelets (details of the structures are shown in Fig. 1). When there was no fruit in a spikelet (all of the fruits were aborted), this spikelet was cut at its proximal region. In this treatment, only bunches 1 to 6 were retained on the tree; older bunches were removed. In Treatment 3 (bunches sprayed), all of the bunches were sprayed with the acaricide, Vertimec 18CE (abamectin, $9 \mathrm{~g} \cdot \mathrm{ha}^{-1}$, dose recommended by the manufacturer) once a month until the end of the evaluations. In Treatment 4 (control plants), no treatment was applied. The wind direction determined the positions of the treated plants within the field to avoid acaricide drift among treated and untreated plants.

At monthly intervals, two fruits were randomly collected from each of bunches 1 to 6 under Treatments 2, 3, and 4, and two fruits were also randomly collected on the available bunches under Treatment 1 . In these fruits, the same procedure for the estimation of the damage level was carried out. After each collection in Treatment 2, the spikelets from the bunches produced were removed distal to the last fruit. The collections continued for 4 months, which is the period required for the first bunch emitted after the implementation of the treatments to reach the harvest point. The damage levels on each tree under Treatments 2, 3, and 4 were obtained from the average scores of the fruits from bunches 2 to 6 . In Treatment 1 , the damage level was obtained from the average scores of fruits from the available bunches during each collection. The average damage levels per tree were transformed to the square root $(\mathrm{x}+0.5)$ and subjected to repeated-measure ANOVA of the general linear model using the indicator Wilks' lambda. The damage levels among different categories of bunch management and over time for each category were compared using the Tukey test at $5 \%$ of significance with Bonferroni adjustment. The statistical analyses were performed using the SAS statistical software (SAS Institute, 2002).

Effect of bunch management on the distribution pattern of damage. The fruits obtained during the last collection (fourth month) were used to determine the average damage level of bunches 2 to 6 from the plants under each treatment. The data were subjected to regression analysis with the average damage level of each bunch as the dependent variable and the age of the bunch as the independent variable using the Proc Reg in SAS. The linear slopes of the fitted models were compared with each other using PROC 
MIXED to test the equality of the linear slopes (SAS Institute, 2002).

\section{Results}

Detection of damage levels before the implementation of bunch management. No significant differences were observed among the damage levels of each plant group $\left(\mathrm{F}_{3,36}=\right.$ $0.52, P=0.67$ ), indicating that the plants submitted to the treatments were equally infested by $A$. guerreronis before the treatments (Fig. 2).

Effect of bunch managements on the damage level of fruit. The ANOVA for repeated measures showed a significant effect of bunch management $\left(\mathrm{F}_{3,36}=94.82, P<0.0001\right)$, of time (Wilks' lambda $=0.2922, \mathrm{~F}=19.98$; $\mathrm{df}=4, P<0.0001)$, and of the interaction of bunch management and time (Wilks' lambda $=$ $0.0605, \mathrm{~F}=13.77$; $\mathrm{df}=12, P<0.0001$ ).

In the evaluations 30 and $60 \mathrm{~d}$ after the implementation of the treatments, the levels of damage were similar for the control plants and the plants with the spikelets removed but lower damage levels were found for plants in the treatment with bunches removed and in plants with bunches sprayed $\left(\mathrm{F}_{3,36}=11.66, P<\right.$ 0.0001 for the 30 -d test; $F_{3,36}=13.19, P<$ 0.0001 for the 60 -d test). After $90 \mathrm{~d}$, the damage levels differed among bunch management, being higher in plants with spikelets removed, followed by control plants, plants with bunches removed, and lower in plants with bunches sprayed $\left(\mathrm{F}_{3,36}=14.81\right.$, $P<0.0001)$. After $120 \mathrm{~d}$, the damage levels were not different for the control plants, plants with the spikelets removed, and plants with the bunches removed, but lower damage levels were found for plants with bunches sprayed $\left(\mathrm{F}_{3,36}=14.81, P<0.0001\right)$ (Fig. $\left.3 \mathrm{~A}\right)$.

Plants in the treatments with bunches removed produced two bunches $30 \mathrm{~d}$ after the implementation of the treatment, and the oldest bunch already had fruits damaged by A. guerreronis. When analyzing each treatment over time, we observed that at $30 \mathrm{~d}$ after the removal of all of the bunches, the damage levels decreased significantly in these plants; at $60 \mathrm{~d}$ after the removal of bunches, the damage levels were similar to either $30 \mathrm{~d}$ or $90 \mathrm{~d}$ after the removal, whereas the damage levels were significantly greater at $120 \mathrm{~d}$ evaluation compared with the previous evaluations $\left(\mathrm{F}_{4,45}=12.98, P<0.0001\right)$. In the plants with the spikelets removed, there was no difference between the damage levels observed before the removal and those observed at 30 and $120 \mathrm{~d}$ after the removal. In the other evaluations (60 and $90 \mathrm{~d}$ after the removal), higher damage levels were found $\left(\mathrm{F}_{4,45}=\right.$ 19.93, $P<0.0001)$. In the controls, no differences were observed between the damage levels at 0 (before the treatment), 30, or $120 \mathrm{~d}$; but greater levels of damage were found 60 and $90 \mathrm{~d}$ compared with the evaluation before the treatment $\left(\mathrm{F}_{4,45}=10.94, P<0.0001\right)$. In the plants with bunches that had been sprayed, the damage level was reduced significantly after acaricide application and remained lower throughout the evaluation periods (30, 60, 90, and $120 \mathrm{~d}$ after the application) $\left(\mathrm{F}_{4,45}=33.88, P<0.0001\right)$ (Fig. 3B).

Effect of bunch management on the distribution pattern of damage. The average damage level increased from bunches 2 to 6 in the control, bunches removed, and spikelets removed plants; for these treatments, the data adequately fitted a linear model with $95 \%, 95 \%$, and $77 \%$, respectively, of the observed variations being accounted for by the models. In the treatment with bunches sprayed, the average damage level remained low (Fig. 4). The calculated slopes were about the same for the control and bunches removed plants (PROC MIXED of SAS for equality of linear coefficient: $t_{95}=-1.48, P=$ 0.3062 ); however, the calculated slopes of the fitted model for spikelets removed plants was lower than those under the control and bunches removed treatments (PROC MIXED of SAS for equality of linear coefficient: $t_{95}=$ $-2.28, P=0.0252$, control plants; $t_{95}=-2.42$, $P=0.0178$, bunches removed).

\section{Discussion}

No damage caused by $A$. guerreronis was observed in the fruits from bunch 1 of all

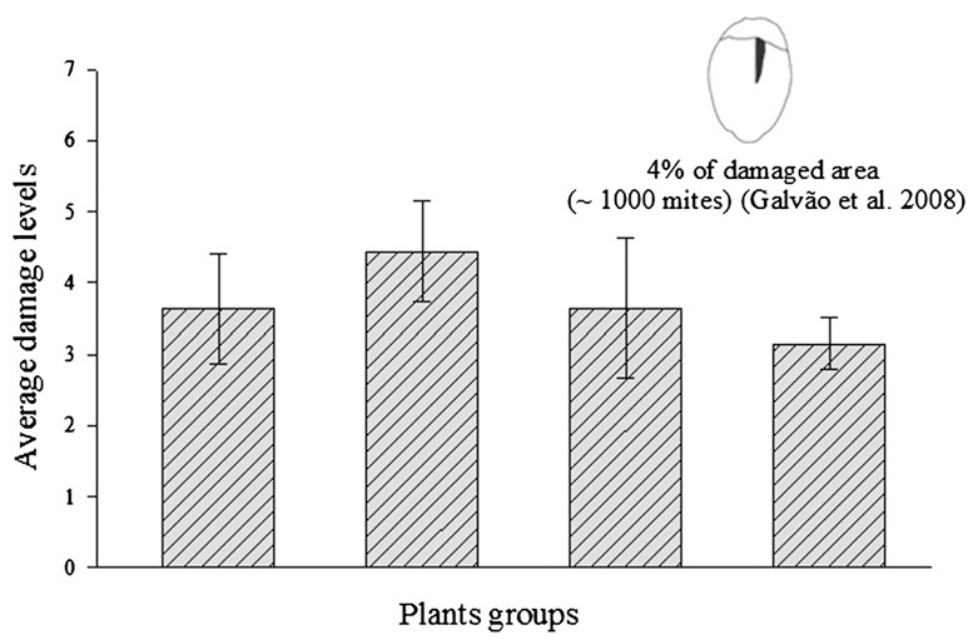

Fig. 2. Mean percentage of fruit surface area damaged by A. guerreronis, from bunches 2 to 6 before the experiment, as estimated using the diagrammatic scale of damage by Galvão et al. (2008). treatments, but damage was frequent in the other bunches. The absence of damage caused by $A$. guerreronis on newly produced fruit can be explained by the tight adherence of the bracts to the fruit at this early stage of development, as suggested by Hall and Espinosa (1981) and Julia and Mariau (1979) and demonstrated by Lima et al. (2012). According to Fernando et al. (2003) and Galvão et al. (2011), the population of $A$. guerreronis is distributed between bunches 2 to 6 on coconut plants, counted from the last open inflorescence. The infestation begins in bunch 2 (Lima et al., 2012), increasing from bunch 2 to 4 , and then declining on older bunches (Fernando et al., 2003, Galvão et al., 2011).

Mites can migrate from older bunches (infested fruits) to younger ones (non-infested fruits) on the same plant by ambulatory movement using the spikelets as a bridge (Galvão et al., 2012; Griffith, 1984; Moore and Alexander, 1987). This migration can occur because of intraspecific competition, the presence of predators, or a low quality of food (Galvão et al., 2012; Griffith, 1984). The spikelets from different bunches touch each other naturally as a result of wind action and the bending of the structure with the increased weight of the fruits. Some authors (Galvão et al., 2012; Moore and Alexander, 1987; Sumangala and Haq, 2005) have reported that the pathway of $A$. guerreronis through the spikelets is a relevant process in the infestation of new bunches. However, as evaluated by the present study, the removal of the spikelets had no significant effect on the damage level of newly produced bunches. This practice only delayed the peak of damage by $\approx 1$ month; the peak was observed at $60 \mathrm{~d}$ in the control plants and at $90 \mathrm{~d}$ in those that had the spikelets removed.

The removal of all of the bunches, and the consequent elimination of the source of infestation, was not sufficient to ensure a low level of infestation during our experiment. Two months after the removal of all of the bunches, the damage levels had been restored to the newly produced bunches (Fig. 3). These results confirm what has been proposed by Moore and Alexander (1987) and reject what has been proposed by Alencar et al. (2001). Moore and Alexander (1987) evaluated aspects of migration and colonization of the coconut palm of the variety Malayan Dwarf (time for the harvest of fruit: 12 months) by the coconut mite. These authors removed all bunches of the plants and after 5 months evaluated the fruits from bunches 3 and 4 and observed that $38 \%$ of fruits were already damaged by the coconut mite. Alencar et al. (2001) evaluated the effect of chemical products and crop management on the control of coconut mite in plants of the variety Green Dwarf (time for the harvest of fruit: 7 months). These authors demonstrated synergic effect between these two approaches, but only the use of crop management reduced the number of damaged fruits by $52 \%$. The different results of these practices probably should not be related to different varieties, because these varieties showed similar responses. One possible explanation for these 

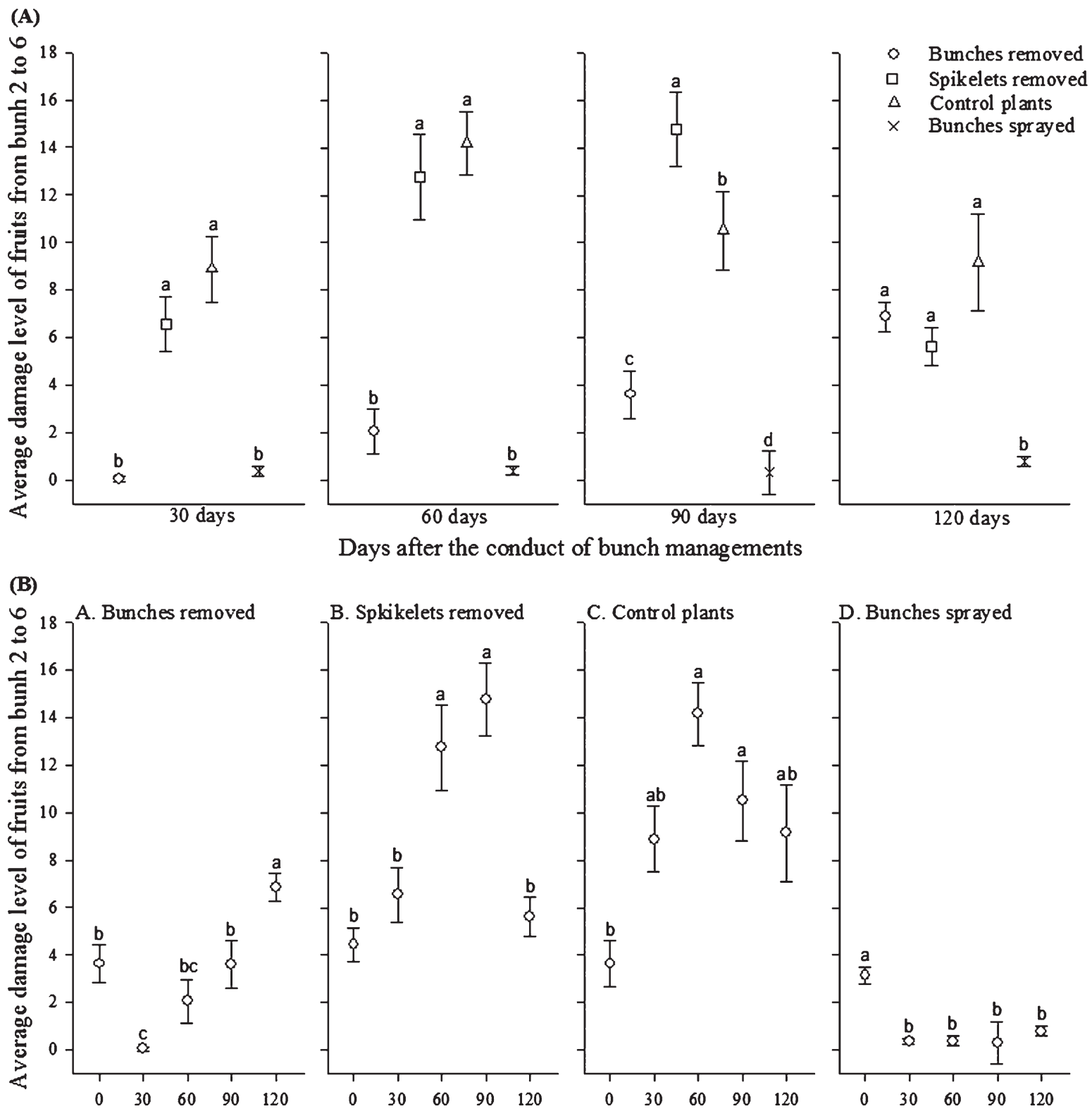

Days after the conduct of bunch managements

Fig. 3. Mean percentage of fruit surface area damaged by A. guerreronis, from bunches 2 to 6 after the experiment started as estimated using the diagrammatic scale of damage by Galvão et al. (2008). Comparisons among treatments are provided for each evaluation period (A) and among evaluation periods within each treatment $(\mathbf{B})$. Means followed by the same letter are not statistically different (Tukey's test; $P \geq 0.05$ ).

conflicting results are the differences in the initial level of the infestation, which may have been low in the study of Alencar et al. (2001) and high in other studies. The rapid recolonization of the fruits from these plants (plants with bunches removed) by A. guerreronis probably occurred as a result of the action of the wind, carrying specimens from one plant to another within the same plantation or between plantations (Galvão et al., 2012; Moore and Alexander, 1987) or by the use of arthropods for phoretic dispersal (Galvão et al., 2012; Griffith, 1984).

The chemical control with abamectin, as applied on a monthly basis, kept the intensity of damage by $A$. guerreronis at low levels. Some authors reported that the insecticides used to control A. guerreronis do not act on the population residing under the perianth (Ferreira et al., 2002). Abamectin probably caused mortality in the population of $A$. guerreronis during its dispersal through the action of the residue on the sprayed fruit. The recommended interval between abamectin applications on coconut in Brazil is $14 \mathrm{~d}$ (recommended by the manufacturer); however, the results presented here suggest that longer intervals between applications should be evaluated, which could result in a lower frequency of applications and, therefore, reduce the costs and environmental risks.

The pattern of distribution of the damage observed in the control, bunches removed, and spikelets removed plants are compatible with what has been reported by other researchers (Fernando et al., 2003; Galvão et al., 2011). In such a pattern, the damage levels increase with the age of the fruit. However, as determined in the present study, the form of management of the bunch can alter the rate of the damage progression or alter the distribution pattern of the damage. As mentioned, removal of the spikelets prevents the migration of the mites from older bunches (infested fruits) to younger bunches (not yet infested); this fact explains a slower progression of damage and a delay in the peak of damage when the spikelets were removed.

This study shows the inefficiency of cultural practices (removal of bunches or the distal portion of spikelets) for the control of A. guerreronis in areas with high levels of infestation. The results presented here demonstrate that these practices only delay the infestation and would not reduce mite damage. 


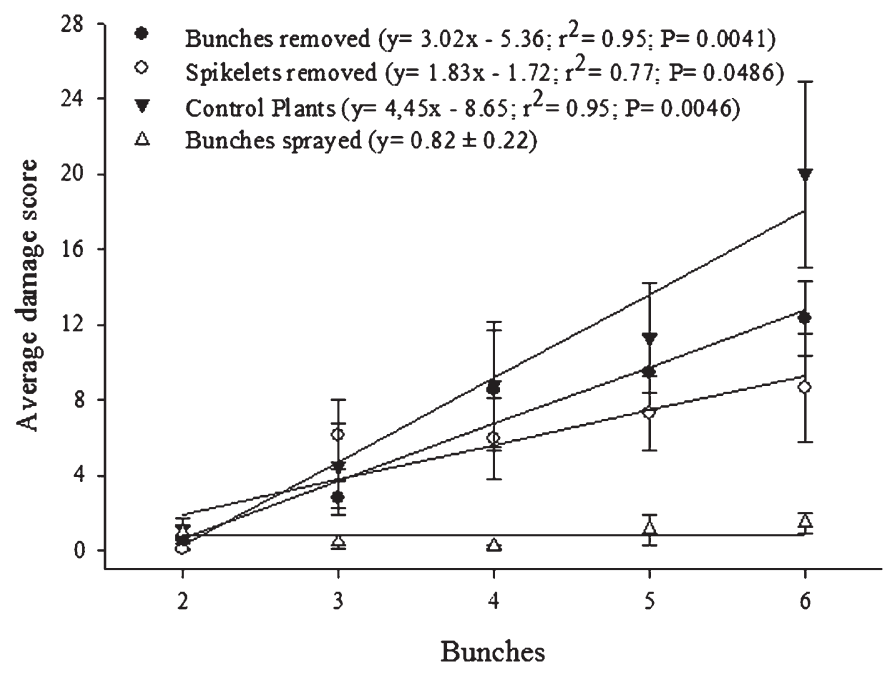

Fig. 4. Damage caused by A. guerreronis to coconuts of bunches of different ages (bunches 2 to 6 ) under each bunch management as estimated using the diagrammatic scale of damage by Galvão et al. (2008).

Thus, other practices should be evaluated to provide an economically viable strategy for small-scale farmers.

\section{Literature Cited}

Alencar, J.A., P.C.G. Alencar, F.N.P. Haji, and F.L. Barbosa. 2001. Efeito do controle cultural e químico sobre o ácaro da necrose do coqueiro, em coco-anão irrigado. Rev. Bras. Frutic. 23:577-579.

Domingos, C.A., J.W.S. Melo, M.G.C. Gondim, Jr., G.J. de Moraes, R. Hanna, L.M. LawsonBalagbo, and P. Schausberger. 2010. Dietdependent life history, feeding preference and thermal requirements of the predatory mite Neoseiulus baraki (Acari: Phytoseiidae). Exp. Appl. Acarol. 50:201-215.

Fernando, L.C.P., N.S. Aratchige, and T.S.G. Peiris. 2003. Distribution patterns of coconut mite, Aceria guerreronis, and its predator $\mathrm{NeO}$ seiulus aff. paspalivorus in coconut palms. Exp. Appl. Acarol. 31:71-78.

Ferreira, J.M.S. 2009. Pragas e métodos de controle ajustados à baixa capacidade de investimento dos pequenos produtores rurais, p. 191-218. In: Cintra, F.L.D., H.R. Fontes, E.E.M. Passos, and J.M.S. Ferreira (eds.). Fundamentos tecnológicos para a revitalização das áreas cultivadas $\mathrm{cm}$ coqueiro gigante no Nordeste do Brasil. Aracaju, Embrapa Tabuleiros Costeiros.

Ferreira, J.M.S., M. Michereff Filho, and P.M.P. Lins. 2002. Pragas de Coqueiro: Características, amostragem, nível de ação e principais métodos de controle, p. 37-57. In: Ferreira, J.M.S. and M. Michereff Filho (eds.). Produção integrada de coco: Práticas fitossanitárias. Aracaju, Embrapa Tabuleiros Costeiros.
Galvão, A.S., M.G.C. Gondim, Jr., G.J. de Moraes, and J.W.S. Melo. 2011. Distribution of Aceria guerreronis and Neoseiulus baraki among and within coconut bunches in northeast Brazil. Exp. Appl. Acarol. 54:373-384.

Galvão, A.S., M.G.C. Gondim, Jr., and S.J. Michereff. 2008. Escala diagramática de dano de Aceria guerreronis Keifer (Acari: Eriophyidae) em coqueiro. Neotrop. Entomol. 37: 723-728.

Galvão, A.S., J.W.S. Melo, V.B. Monteiro, D.B. Lima, G.J. de Moraes, and M.G.C. Gondim, Jr. 2012. Dispersal strategies of Aceria guerreronis (Acari: Eriophyidae), a coconut pest. Exp. Appl. Acarol. 57:1-13. Eriophyes guerreronis (Keifer), in the coconut groves of Trinidad and Tobago, p. 128-132. In: Webb, R., W. Knausenberger, and L. Yntema (eds.). Proc. of the 20th annual meeting of the Caribbean Food Crops Society. East Caribbean Cent., Coll. Virgin Islands and Caribbean Food Crops Soc.

Hall, R.A. and B.A. Espinosa. 1981. The coconut mite, Eriophyes guerreornis, with special reference to the problem in Mexico, p. 113120. In: Proc. of the British Crop Protection Conference-Pests and diseases. British Crop Protection Council, Farnham, UK.

Howard, F.W. 2008. Coconut Mite, Aceria guerreronis (Acari: Eriophyidae), p. 952-956. In: Capinera, J.L. (ed.). Encyclopedia of entomology. Springer, The Netherlands.

Julia, J.F. and D. Mariau. 1979. Nouvelles recherché en Cote d'Ivoire sur Eriophyes guerreronis K., acarien ravageur des noix du cocotier. Oléagineux. 34:181-189.

Kottek, M., J. Grieser, C. Beck, B. Rudolf, and F. Rubel. 2006. World Map of the Köppen-Geiger
Griffith, R. 1984. The problem of the coconut mite, climate classification updated. Meteorol. Z . 15:259-263.

Lawson-Balagbo, L.M., M.G.C. Gondim, Jr., G.J. Moraes, R. Hanna, and P. Schausberger. 2008. Exploration of the acarine fauna on coconut palm in Brazil with emphasis on Aceria guerreronis (Acari: Eriophyidae) and its natural enemies. Bull. Entomol. Res. 98:83-96.

Lima, D.B., J.W.S. Melo, M.G.C. Gondim, Jr., and G.J. Moraes. 2012. Limitations of Neoseiulus baraki and Proctolaelaps bickleyi as control agents of Aceria guerreronis. Exp. Appl. Acarol. 56:233-246.

Mariau, D. 1986. Comportement de Eriophyes guerreronis Keifer à l'egard de différentes variétés de cocotiers. Oléagineux. 41:499-505.

Melo, J.W.S., D.B. Lima, A. Pallini, J.E.M. Oliveira, and M.G.C. Gondim, Jr. 2011. Olfactory response of predatory mites to vegetative and reproductive parts of coconut palm infested by Aceria guerreronis. Exp. Appl. Acarol. 55:191202.

Moore, D. 2000. Non-chemical control of Aceria guerreronis on coconuts. Biocontrol News Infor. 21:83-87.

Moore, D. and F.W. Howard. 1996. Coconuts, p. 561-570. In: Lindquist, E.E., M.W. Sabelis, and J. Bruin (eds.). Eriophyoid mites-Their biology, natural enemies and control. Elsevier Science Publishing, Amsterdam, The Netherlands.

Moore, D. and L. Alexander. 1987. Aspects of migration and colonization of the coconut palm by the coconut mite, Eriophyes guerreronis (Keifer) (Acari: Eriophyidae). Bull. Entomol. Res. 77:641-650.

Moore, D. and L. Alexander. 1990. Resistance of coconuts in St. Lucia to attack by the coconut mite Eriophyes guerreronis Keifer. Trop. Agr. 67:33-36.

Moore, D., L. Alexander, and R.A. Hall. 1989. The coconut mite, Eriophyes guerreronis Keifer in St Lucia yield losses and attempts to control it with acaricide, polybutene e Hirsutella fungus. Trop. Pest Manage. 35:83-89.

Negloh, K., R. Hanna, and P. Schausberger. 2011. The coconut mite, Aceria guerreronis, in Benin and Tanzania: Occurrence, damage and associated acarine fauna. Exp. Appl. Acarol. 55: 361-374.

Ramaraju, K., K. Natarajan, P.C.S. Babu, S. Palnisamy, and R.J. Rabindra. 2002. Studies on coconut eriophyid mite, Aceria guerreronis Keifer in Tamil Nadu, Índia, p. 13-31. In: Fernando, L.C.P., G.J. de Moraes, and I.R. Wickramananda (eds.). Proc. of the International Workshop on Coconut Mite (Aceria guerreronis). Coconut Research Institute, Sri Lanka.

SAS Institute. 2002. SAS/STAT User's guide, version 8.02 , TS level 2MO. SAS Institute Inc., Cary, NC.

Sumangala, K. and M.A. Haq. 2005. Diurnal periodicity and dispersal of coconut mite, Aceria guerreronis Keifer. J. Entomol. Res. 29:303307. 